\title{
Desulfovibrio butyratiphilus sp. nov., a Gram- negative, butyrate-oxidizing, sulfate-reducing bacterium isolated from an anaerobic municipal sewage sludge digester
}

\author{
Daisuke Suzuki, Atsuko Ueki, Toshiko Shizuku, Yoshimi Ohtaki \\ and Katsuji Ueki
}

Correspondence

Atsuko Ueki

uatsuko@tds1.tr.yamagata-u.ac.jp
Faculty of Agriculture, Yamagata University, Wakaba-machi 1-23, Tsuruoka, Yamagata 997-8555, Japan

\begin{abstract}
Strictly anaerobic, mesophilic, sulfate-reducing bacterial strains were isolated from two anaerobic municipal sewage sludge digesters. One representative strain $\left(B S Y^{\top}\right)$ was characterized phenotypically and phylogenetically. Cells were Gram-negative, motile by means of a single polar flagellum, non-spore-forming, curved rods. Cells had desulfoviridin and cytochrome type $c$. Catalase and oxidase activities were not detected. The optimum $\mathrm{NaCl}$ concentration for growth was $0.5 \%(\mathrm{w} / \mathrm{v})$. The optimum temperature was $35^{\circ} \mathrm{C}$ and the optimum $\mathrm{pH}$ was 7.1. Strain $\mathrm{BSY}^{\top}$ utilized butyrate, 2-methylbutyrate, valerate, pyruvate, lactate, ethanol, 1-propanol, butanol and $\mathrm{H}_{2}$ as electron donors for sulfate reduction. This strain grew lithoautotrophically with $\mathrm{H}_{2} / \mathrm{CO}_{2}$ under sulfate-reducing conditions. Most organic electron donors were incompletely oxidized to mainly acetate, whereas 2-methylbutyrate and valerate were oxidized to equivalent amounts of acetate and propionate. Strain $B S Y^{\top}$ utilized thiosulfate as an electron acceptor, and grew with pyruvate in the absence of electron acceptors. The genomic DNA G+C content of strain BSY ${ }^{\top}$ was $63.3 \mathrm{~mol} \%$. Menaquinone MK-6 $\left(\mathrm{H}_{2}\right)$ was the major respiratory quinone. Major cellular fatty acids were $\mathrm{C}_{14: 0}, \mathrm{C}_{16: 0}, \mathrm{C}_{16: 1} \omega 7$ and $\mathrm{C}_{18: 1} \omega 7$. Phylogenetic analyses based on 16S rRNA and dissimilatory sulfite-reductase $\beta$-subunit gene sequences assigned strain $\mathrm{BSY}^{\top}$ to the genus Desulfovibrio in the family Desulfovibrionaceae within the class Deltaproteobacteria. Its closest recognized relative based on 16S rRNA gene sequences was the type strain of Desulfovibrio putealis (95.3\% similarity). On the basis of significant differences in 16S rRNA gene sequences and phenotypic characteristics, the sewage sludge strains are considered to represent a single novel species of the genus Desulfovibrio, for which the name Desulfovibrio butyratiphilus sp. nov. is proposed. The type strain is $\mathrm{BSY}^{\top}\left(=\mathrm{JCM} 15519^{\top}=\mathrm{DSM} 21556^{\top}\right)$.
\end{abstract}

Butyrate is an important intermediate in the anaerobic degradation of organic matter in various anaerobic ecosystems. Because the oxidation of butyrate is usually thermodynamically unfavourable under anaerobic conditions, it is generally degraded by syntrophic interactions between $\mathrm{H}_{2}$-producing acetogenic bacteria and $\mathrm{H}_{2}$-utilizing methanogens in methanogenic conditions (Stams, 1994;

Abbreviation: DSR, dissimilatory sulfite-reductase.

The GenBank/EMBL/DDBJ accession numbers for the 16S rRNA gene sequences of strains BST, BST-B, BST-C, BSY ${ }^{\top}$ and $B S Y-C$ are AB303302, AB303303, AB303304, AB303305 and AB303306, respectively. The accession number for the dissimilatory sulfitereductase $\beta$-subunit gene sequence of strain $\mathrm{BSY}^{\top}$ is $\mathrm{AB} 490775$.

A table comparing the cellular fatty acid compositions of strain $\mathrm{BSY}^{\top}$ and Desulfovibrio sulfodismutans $\mathrm{ThACO}^{\top}$ and Desulfovibrio carbinolicus EDK82 ${ }^{\top}$ is available as supplementary material with the online version of this paper.
Schink, 1997; Sekiguchi et al., 2000; Zhang et al., 2004). However, in the presence of sulfate as an electron acceptor, some sulfate-reducing bacterial species oxidize butyrate either completely to $\mathrm{CO}_{2}$ or incompletely to acetate (Rabus et al., 2000). These sulfate-reducing bacterial species belong to the families Desulfobacteraceae (Cravo-Laureau et al., 2004; Kuever et al., 2005; Balk et al., 2008; Suzuki et al., 2008), Desulfohalobiaceae (Belyakova et al., 2006) and Syntrophobacteraceae (Beeder et al., 1995; Sievert \& Kuever, 2000; Tanaka et al., 2000) in the class Deltaproteobacteria or to the genus Desulfotomaculum in the phylum Firmicutes (Daumas et al., 1988; Tasaki et al., 1991; Fardeau et al., 1995; Kuever et al., 1999; Vandieken et al., 2006).

In the present study, we isolated five sulfate-reducing bacterial strains (BSY ${ }^{\mathrm{T}}$, BSY-C, BST, BST-B and BST-C) from two anaerobic municipal sewage sludge digesters via enrichment cultures. All strains reduced sulfate with 
butyrate as an electron donor and were closely related to species in the genus Desulfovibrio based on initial 16S rRNA gene sequence analysis. Strain $\mathrm{BSY}^{\mathrm{T}}$ was selected as a representative and was further characterized comprehensively. Butyrate-oxidizing Desulfovibrio species have not previously been described, and differences in phylogenetic and phenotypic characteristics between strain $\mathrm{BSY}^{\mathrm{T}}$ and related Desulfovibrio species supported the proposal that it represents a novel species of the genus Desulfovibrio.

Samples obtained from two anaerobic digesters treating municipal sewage sludge (Yokohama and Tsuruoka in Japan) were used for isolation of bacterial strains. Each sewage sludge sample was inoculated $(0.5 \mathrm{ml}$ each) into defined liquid medium $(9.5 \mathrm{ml})$ containing $20 \mathrm{mM}$ sodium butyrate as described below under the flow of $\mathrm{O}_{2}$-free gas $\left(95: 5 \quad \mathrm{~N}_{2} / \mathrm{CO}_{2}\right)$. Cultures $(0.1 \mathrm{ml})$ showing sulfate reduction were transferred to the same fresh medium $(10 \mathrm{ml})$. After several subcultures, sulfate-reducing bacteria were isolated from the cultures by using the anaerobic roll tube method (Hungate, 1966). Black colonies that appeared in the agar were picked and five isolates (strains BSY ${ }^{\mathrm{T}}$ and BSY-C from Yokohama and strains BST, BST-B and BST-C from Tsuruoka) were obtained after purification procedures. The novel strains displayed high levels of 16S rRNA gene sequence similarity (about 99-100 \%) and showed almost identical phenotypic characteristics, including utilization of both electron donors and acceptors (see further below). Thus, strain $\mathrm{BSY}^{\mathrm{T}}$ was selected as a representative for further characterization.

The following defined medium was used for the enrichment culture, isolation and the general physiological characterization of the strains (per litre distilled water): $0.5 \mathrm{~g} \mathrm{KH}_{2} \mathrm{PO}_{4}, 1.0 \mathrm{~g} \mathrm{NH}_{4} \mathrm{Cl}, 2.5 \mathrm{~g} \mathrm{MgSO}_{4} .7 \mathrm{H}_{2} \mathrm{O}, 0.1 \mathrm{~g}$ $\mathrm{CaCl}_{2} \cdot 2 \mathrm{H}_{2} \mathrm{O}, 1 \mathrm{mg}$ sodium resazurin, $10 \mathrm{ml}$ trace element solution (Widdel et al., 1983), $1.0 \mathrm{~g} \mathrm{NaCl}$ and $0.5 \mathrm{~g} \mathrm{~L}-$ cysteine. $\mathrm{HCl} . \mathrm{H}_{2} \mathrm{O}$ with appropriate electron donors (Ueki et al., 1980; Widdel \& Bak, 1992). pH was adjusted to 7.4-7.5 with $1 \mathrm{M} \mathrm{NaOH}$. Agar (Difco) $(1.5 \%$, w/v) medium with sodium butyrate $(20 \mathrm{mM})$ was used for the anaerobic roll tube method for isolation as well as slant cultures for maintenance of isolates. Cultivation and transfer of the enrichment cultures and isolates were carried out under an $\mathrm{O}_{2}$-free $\mathrm{N}_{2} / \mathrm{CO}_{2}(95: 5)$ atmosphere. Cultivation was at $30{ }^{\circ} \mathrm{C}$ unless stated otherwise.

The Gram reaction and cell morphology were confirmed by using light microscopy. Cell motility was examined by using phase-contrast microscopy. Staining of flagella was carried out according to Blenden \& Goldberg (1965). Physiological tests were performed according to the methods described by Suzuki et al. (2007a, b, c). Utilization of electron donors by the isolates was determined by using the defined medium containing each compound at a final concentration of $20 \mathrm{mM}$. Utilization of $\mathrm{H}_{2}$ as an electron donor was determined in the presence or absence of acetate $(5 \mathrm{mM})$ as an organic carbon source under an $\mathrm{H}_{2} / \mathrm{CO}_{2}(90: 10)$ atmosphere. Utilization of electron acceptors other than sulfate was determined in sulfate-free medium containing the same concentrations of chloride in place of sulfate in the defined medium (Suzuki et al., 2007a, b, c). Substrate utilization in the absence of electron acceptors was determined in sulfate-free medium (Suzuki et al., 2007a, b, c). Fatty acids and amino acids were used in the form of sodium salts and were added to the medium from sterilized stock solutions. Utilization of each electron donor or acceptor was determined by comparing growth in the presence or absence of each compound as well as measurement of the concentration in the medium after cultivation. Growth was monitored by direct measurement of the optical density at $660 \mathrm{~nm}$ $\left(\mathrm{OD}_{660}\right)$ of the culture tubes with a spectrophotometer.

Volatile fatty acids, non-volatile fatty acids, alcohols, gases, sulfate, sulfite, thiosulfate and nitrate were analysed as described by Akasaka et al. (2003a), Nakamoto et al. (1996) and Ueki et al. (1986). The presence of desulfoviridin in cells was determined according to the method of Postgate (1959). The presence and type of cytochrome were determined by measuring an air-oxidized/dithionite-reduced difference spectrum of cell-free extract (U-2010 spectrophotometer; Hitachi). Genomic DNA extracted according to the method described by Akasaka et al. (2003b) was digested with P1 nuclease by using a YAMASA GC kit (Yamasa Shoyu) and its $\mathrm{G}+\mathrm{C}$ content was measured by HPLC (L-7400; Hitachi), the chromatograph being equipped with a $\mu$ Bondapak $\mathrm{C} 18$ column $(3.9 \times 300 \mathrm{~mm}$; Waters). Isoprenoid quinones were extracted as described by Komagata \& Suzuki (1987) and were analysed by using a mass spectrometer (JMS-SX102A; JEOL). Whole-cell fatty acids were converted to methyl esters according to the method of Miller (1982). Methyl esters of cellular fatty acids were analysed with a gas chromatograph (Hewlett Packard Hp6890 or Hitachi G3000) equipped with an Ultra 2 column (Hewlett Packard). Fatty acids were identified by equivalent chain-length (Miyagawa et al., 1979; Ueki \& Suto, 1979) according to the protocol of TechnoSuruga Co., Ltd based on the MIDI microbial identification system (Microbial ID) of Moore et al. (1994).

Extraction of DNA and PCR amplification of the 16S rRNA genes of the novel strains were carried out according to the methods described by Akasaka et al. (2003b). The PCRamplified 16S rRNA gene (by using primer set $27 \mathrm{~F}$ and 1492R) was sequenced via a Thermo Sequenase Primer Cycle Sequencing kit (Amersham Biosciences) and a model of 4000L DNA sequencer (Li-COR). Multiple alignments of the sequence with reference sequences in GenBank/ EMBL/DDBJ were performed with the BLAST program (Altschul et al., 1997). A phylogenetic tree was constructed with the neighbour-joining method (Saitou \& Nei, 1987) by using the CLUSTAL W program (Thompson et al., 1994) as well as the maximum-likelihood program (DNAML) of the PHYLIP 3.66 package (Felsenstein, 2006). All gaps and unidentified base positions in the alignments were excluded before assemblage. 
A partial sequence of the gene encoding the $\alpha$ - and $\beta$ subunits of dissimilatory sulfite-reductase (DSR) was amplified by using primer set P94-F and P93-R (Karkhoff-Schweizer et al., 1995), with DNA extracted from cells of strain $\mathrm{BSY}^{\mathrm{T}}$. The PCR product was cloned by using the pGEM-T Easy vector (Promega) and was recovered from each colony by PCR with primers T7W and SP6W (as a primer set for the pGEM-T Easy vector sequence flanking the insertion) (Watanabe et al., 2000). The partial sequence of the gene encoding the $\beta$-subunit of DSR within the PCR product was sequenced, and phylogenetic analysis was performed according to the methods described above for the 16S rRNA gene. Amplification of the DSR gene sequence with primer set DSR1F/DSR4R (Wagner et al., 1998) was unsuccessful.

Cells of strain $\mathrm{BSY}^{\mathrm{T}}$ were Gram-negative, relatively large curved rods with rounded ends, $0.8-0.9 \mu \mathrm{m}$ wide and 2.4 $5.6 \mu \mathrm{m}$ long. Cells usually occurred singly and spore formation was not observed (Fig. 1). Cells were motile by means of a single polar flagellum. Cells formed greyish, thin colonies on agar slant medium. Strain BSY ${ }^{\mathrm{T}}$ did not grow aerobically. Desulfoviridin was detected in the cell extract. A difference absorption spectrum of air-oxidized/ dithionite-reduced cell extract showed peaks at 418 and $553 \mathrm{~nm}$, which indicated the presence of cytochrome type $c$. Catalase and oxidase activities were not detected.

Strain $\mathrm{BSY}^{\mathrm{T}}$ did not grow in the absence of added electron donors and required carbonate or bicarbonate for growth in the defined medium. Table 1 gives details of consumption of electron donors and compounds produced by strain $\mathrm{BSY}^{\mathrm{T}}$ by sulfate reduction as well as the growth rate with each electron donor. In the presence of sulfate as an electron acceptor, strain $\mathrm{BSY}^{\mathrm{T}}$ utilized butyrate, 2-methylbutyrate, valerate, pyruvate, lactate, ethanol, 1-propanol,

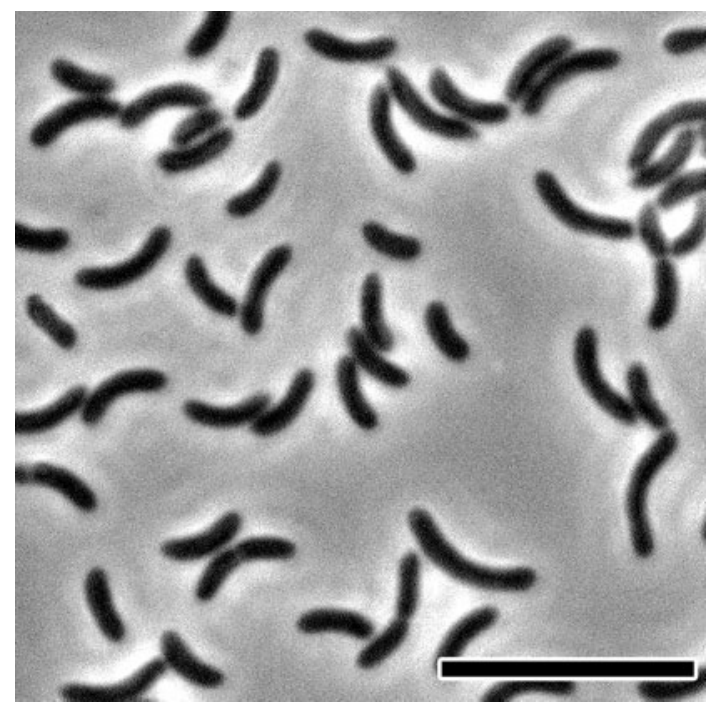

Fig. 1. Phase-contrast photomicrograph of cells of strain $B S Y^{\top}$ grown anaerobically in defined medium. Bar, $10 \mu \mathrm{m}$. butanol and $\mathrm{H}_{2}$. It showed weak lithoautotrophic growth with $\mathrm{H}_{2} / \mathrm{CO}_{2}$ in the absence of acetate under sulfatereducing conditions.

Butyrate, pyruvate, lactate, ethanol and butanol were oxidized to acetate, whereas almost equivalent amounts of acetate and propionate were produced during anaerobic growth with 2-methylbutyrate and valerate. When the time-courses of consumption of the latter two electron donors were examined, the same amounts of acetate and propionate accumulated simultaneously in the medium accompanied by a decrease in the concentration of each electron donor as well as sulfate. 1-Propanol was oxidized to propionate. Thus, strain $\mathrm{BSY}^{\mathrm{T}}$ had an incomplete-type oxidation profile of organic substrates. The stoichiometric ratio of butyrate oxidation (butyrate oxidized/sulfate reduced/acetate produced) was about $2: 1: 4$. The ratios for 2-methylbutyrate and valerate (2-methylbutyrate or valerate/sulfate/acetate/propionate) were about $2: 1: 2: 2$. These ratios were consistent with theoretical values for the incomplete oxidation of the substrates through the $\beta$ oxidation pathway. When cells of strain $\mathrm{BSY}^{\mathrm{T}}$ were cultivated with butanol as an electron donor, acetate was detected as a major product (butanol/sulfate/acetate, $1: 1: 2$ ). During the time-course of sulfate reduction with butanol, a small amount of butyrate was produced after sulfate was almost exhausted. When strain $\mathrm{BSY}^{\mathrm{T}}$ was cultivated with $\mathrm{H}_{2} / \mathrm{CO}_{2}$ +acetate, a trace amount of butyrate was also detected.

Strain $\mathrm{BSY}^{\mathrm{T}}$ grew with butyrate as the preferred electron donor without a significant lag period after inoculation of cells to the medium. In contrast, relatively long lag periods were observed for growth with 2-methylbutyrate (5-6 days after inoculation) and valerate (7-8 days). Lag periods were not significantly shortened even after successive subcultures in the medium containing the same electron donors. After beginning of growth as observed by an increase in turbidity of the culture, however, strain BSY ${ }^{\mathrm{T}}$ grew rapidly at almost the same growth rates as that with butyrate.

No growth was observed with the following electron donors for sulfate reduction: formate, acetate, propionate, isobutyrate, isovalerate, caprylate, crotonate, fumarate, malate, succinate, methanol, 2-propanol, glycerol, glycine, L-alanine, L-serine, L-aspartate, L-glutamate, D-glucose, Dfructose and yeast extract $(0.05 \%, \mathrm{w} / \mathrm{v})$.

Strain BSY ${ }^{\mathrm{T}}$ utilized thiosulfate as an electron acceptor with butyrate as an electron donor. The growth rate was almost the same as that with sulfate. The stoichiometric ratio (butyrate/ thiosulfate/acetate) was about $2: 1: 4$. The strain did not use sulfite, nitrate or fumarate as electron acceptors. In the absence of electron acceptors, pyruvate supported weak growth of strain $\mathrm{BSY}^{\mathrm{T}}$. The strain produced acetate $\left(0.9 \mathrm{mmol} \mathrm{l}^{-1}\right)$, butyrate $\left(1.4 \mathrm{mmol} \mathrm{l}^{-1}\right), \mathrm{CO}_{2}\left(1.4 \mathrm{mmol} \mathrm{l}^{-1}\right)$ and a trace amount of $\mathrm{H}_{2}\left(1.4 \mathrm{mmol} \mathrm{l}^{-1}\right)$ by pyruvate oxidation. It did not oxidize butyrate, lactate, fumarate or malate in the absence of electron acceptors. 
Table 1. Utilization of substrates as electron donors and compounds produced by strain BSY ${ }^{\top}$ by sulfate reduction ND, Not determined; -, absent.

\begin{tabular}{|c|c|c|c|c|c|}
\hline \multirow[t]{2}{*}{ Electron donor } & \multirow{2}{*}{$\begin{array}{c}\text { Electron donors } \\
\text { consumed }\left(\mathrm{mmol} \mathrm{l}^{-1}\right)\end{array}$} & \multirow{2}{*}{$\begin{array}{l}\text { Sulfate reduced } \\
\qquad\left(\mathrm{mmol} \mathrm{l}^{-1}\right)\end{array}$} & \multicolumn{2}{|c|}{ Compounds produced $\left(\operatorname{mmol~} \mathbf{l}^{-1}\right)$} & \multirow{2}{*}{$\begin{array}{l}\text { Specific growth rate } \\
\qquad\left(h^{-1}\right)\end{array}$} \\
\hline & & & Acetate & Others & \\
\hline No addition & $\mathrm{ND}$ & $\mathrm{ND}$ & 0.2 & - & $\mathrm{ND}$ \\
\hline Butyrate & 20.0 & 9.3 & 41.2 & - & 0.058 \\
\hline 2-Methylbutyrate & 16.3 & 8.7 & 16.7 & Propionate (16.3) & 0.053 \\
\hline Valerate & 15.7 & 7.1 & 16.4 & Propionate (15.6) & 0.050 \\
\hline Pyruvate & 7.8 & 2.3 & 10.4 & - & 0.013 \\
\hline Lactate & 4.6 & 2.2 & 4.5 & - & 0.013 \\
\hline Ethanol & 17.9 & 7.9 & 19.6 & - & 0.025 \\
\hline 1-Propanol & 18.3 & 7.6 & - & Propionate (16.7) & 0.025 \\
\hline Butanol & 8.3 & 8.5 & 15.4 & Butyrate (1.6) & 0.031 \\
\hline $\mathrm{H}_{2} / \mathrm{CO}_{2}+$ acetate & $\mathrm{ND}$ & 9.4 & - & Butyrate (0.3) & 0.063 \\
\hline $\mathrm{H}_{2} / \mathrm{CO}_{2}$ & ND & 3.5 & - & - & 0.012 \\
\hline
\end{tabular}

In the presence of butyrate as an electron donor, the $\mathrm{NaCl}$ concentration range for growth of strain $\mathrm{BSY}^{\mathrm{T}}$ was $0-2.0 \%$ $(\mathrm{w} / \mathrm{v})$ with an optimum at $0.5 \%(\mathrm{w} / \mathrm{v})$, temperature range for growth was $25-40{ }^{\circ} \mathrm{C}$ with an optimum at $35{ }^{\circ} \mathrm{C}$, and $\mathrm{pH}$ range for growth was $6.2-8.0$ with an optimum at $\mathrm{pH} 7.1$.

The $\mathrm{G}+\mathrm{C}$ content of the genomic DNA of strain $\mathrm{BSY}^{\mathrm{T}}$ was $63.3 \mathrm{~mol} \%$. The major respiratory quinone was menaquinone MK-6 $\left(\mathrm{H}_{2}\right)$. The strain had $\mathrm{C}_{18: 1} \omega 7(32.1 \%), \mathrm{C}_{16: 1} \omega 7$ $(25.5 \%), \mathrm{C}_{14: 0}(24.1 \%)$ and $\mathrm{C}_{16: 0}(10.2 \%)$ as major cellular fatty acids, with $\mathrm{C}_{12: 0}, \mathrm{C}_{15: 0}, \mathrm{C}_{18: 0}, \mathrm{C}_{16: 1} \omega 5$, $\mathrm{C}_{18: 1} \omega 9, \mathrm{C}_{18: 1} \omega 5$, iso- $\mathrm{C}_{12: 0}$, anteiso- $\mathrm{C}_{15: 0}, \mathrm{C}_{16: 0} 2-\mathrm{OH}$, $\mathrm{C}_{14: 0}$ dimethylacetal, $\mathrm{C}_{16: 0}$ dimethylacetal, $\mathrm{C}_{17: 0}$ cyclopropane and $\mathrm{C}_{19}$ cyclopropane as minor or trace components.

An almost full-length 16S rRNA gene sequence (1450 bp) of strain BSY ${ }^{\mathrm{T}}$ was determined. Phylogenetic analysis based on 16S rRNA gene sequences indicated that strain $\mathrm{BSY}^{\mathrm{T}}$ was affiliated with the class Deltaproteobacteria and was related to members of the genus Desulfovibrio in the family Desulfovibrionaceae (Fig. 2). Its closest relative was 'Uncultured deltaproteobacterium clone MBNTA bac-1' (95.4\% 16S rRNA gene sequence similarity). The closest recognized relative of strain $\mathrm{BSY}^{\mathrm{T}}$ was the type strain of Desulfovibrio putealis (95.3\% 16S rRNA gene sequence similarity); the next closest relatives were the type strains of Desulfovibrio sulfodismutans and Desulfovibrio carbinolicus (with much lower sequence similarities of 90.6 and $90.5 \%$, respectively). Together with the other strains (BSY-C, BST, BST-B and BST-C) isolated in this study, strain BSY formed a distinct cluster within the Desulfovibrio clade (Fig. 2). Strain $B S Y^{\mathrm{T}}$ was distantly related to the type strain of the type species of the genus Desulfovibrio, Desulfovibrio desulfuricans ( $86.7 \%$ 16S rRNA gene sequence similarity). The tree topology evaluated by using the maximumlikelihood method was almost the same as that obtained with the neighbour-joining method.
The partial sequence (730 bp) of the $\beta$-subunit of the DSR gene of strain BSY ${ }^{\mathrm{T}}$ was determined. Phylogenetic analysis based on DSR gene sequences showed that strain $\mathrm{BSY}^{\mathrm{T}}$ was related most closely to 'Uncultured sulfate-reducing bacterium clone GranDSR12' (83.5 \% sequence similarity). Its closest recognized relatives were the type strains of Desulfovibrio alkalitolerans and Desulfovibrio aminophilus (73.4\% DSR gene sequence similarity). Thus, on the basis of DSR gene sequence analysis, strain $\mathrm{BSY}^{\mathrm{T}}$ was also closely related to species of the genus Desulfovibrio. The level of DSR gene sequence similarity between strain $\mathrm{BSY}^{\mathrm{T}}$ and the type strain of Desulfovibrio carbinolicus was $66.7 \%$. The sequences of Desulfovibrio putealis and Desulfovibrio sulfodismutans were not available.

Strain $\mathrm{BSY}^{\mathrm{T}}$ shared major characteristics with Desulfovibrio species such as cell morphology, presence of cytochrome type $c$ and desulfoviridin as a sulfite-reductase, incomplete oxidation of electron donors, and mesophilic growth (Kuever et al., 2005). Strain BSY ${ }^{\mathrm{T}}$ contained MK-6 $\left(\mathrm{H}_{2}\right)$ as the major respiratory quinone, consistent with data for the genus Desulfovibrio (Collins \& Widdel, 1986). However, strain $\mathrm{BSY}^{\mathrm{T}}$ could be distinguished from recognized Desulfovibrio species based on utilization of electron donors, namely utilization of butyrate, 2-methylbutyrate and valerate as electron donors for sulfate reduction. Some sulfate-reducing bacterial species belonging to the families Desulfobacteraceae and Syntrophobacteraceae utilize butyrate as well as longer-chain fatty acids (Beeder et al., 1995; Sievert \& Kuever, 2000; Tanaka et al., 2000; Cravo-Laureau et al., 2004; Kuever et al., 2005; Balk et al., 2008), although 2methylbutyrate is utilized by only a few sulfate-reducing bacterial species belonging to the genera Desulfobacterium, Desulfococcus, Desulfonema and Desulfosarcina (Kuever et al., 2005). Given that sulfate-reducing bacterial strains with the same properties as strain $\mathrm{BSY}^{\mathrm{T}}$ were enriched and isolated from two digesters located distantly from each other, it appears that such bacteria are widely distributed in anaerobic municipal sewage sludge digesters. 


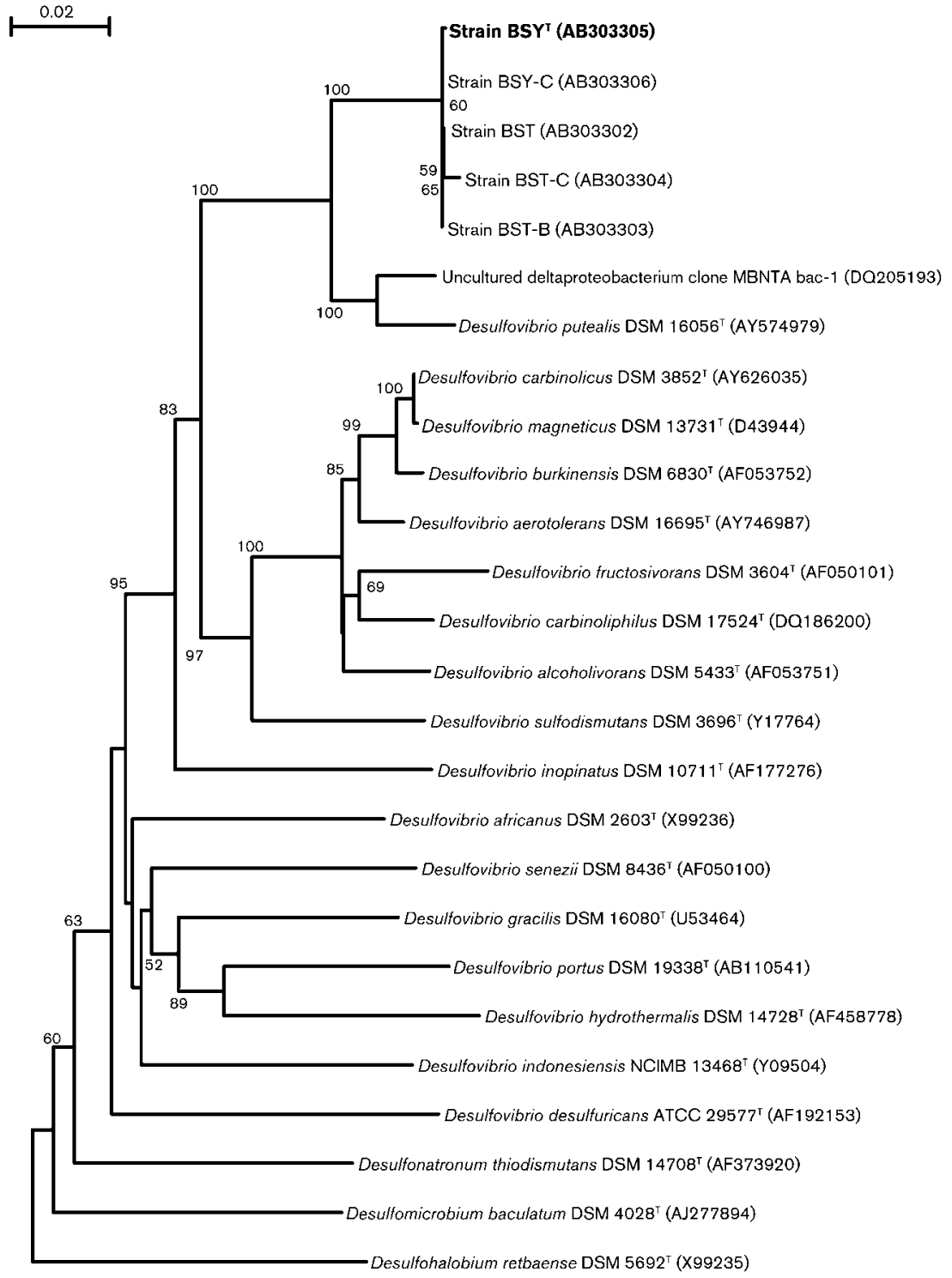

Fig. 2. Neighbour-joining tree, based on $16 \mathrm{~S}$ rRNA gene sequences, showing the phylogenetic relationship between strain $B S Y^{\top}$ and related members of the order Desulfovibrionales. Bootstrap values (expressed as percentages of 1000 replications) above $50 \%$ are shown at branch nodes. Desulfohalobium retbaense DSM $5692^{\top}$ was used as an outgroup. Bar, $2 \%$ estimated sequence divergence.
The physiological characteristics of strain $\mathrm{BSY}^{\mathrm{T}}$ were compared with those of the type strains of Desulfovibrio putealis, Desulfovibrio sulfodismutans and Desulfovibrio carbinolicus (Table 2). In addition to data for butyrate, 2methylbutyrate and valerate, the range of electron donor utilization (such as formate, fumarate, malate, succinate and propanol) of strain $\mathrm{BSY}^{\mathrm{T}}$ was not consistent with these three species. Strain $\mathrm{BSY}^{\mathrm{T}}$ was unable to utilize sulfite or fumarate as electron acceptors, whereas Desulfovibrio putealis, Desulfovibrio sulfodismutans and Desulfovibrio carbinolicus were able to utilize at least one of them. In the absence of electron acceptors, strain BSY and Desulfovibrio sulfodismutans did not utilize fumarate or malate, whereas Desulfovibrio putealis and Desulfovibrio carbinolicus utilize both.

The cellular fatty acid profiles of strain $\mathrm{BSY}^{\mathrm{T}}$ and the type strains of Desulfovibrio sulfodismutans and Desulfovibrio carbinolicus are compared in Supplementary Table S1 (available in IJSEM Online); the profile for Desulfovibrio putealis has not been reported. Most species of the genus Desulfovibrio have branched-chain fatty acids such as iso$\mathrm{C}_{15: 0}$, anteiso- $\mathrm{C}_{15: 0}$, iso- $\mathrm{C}_{17: 0}$ or iso- $\mathrm{C}_{17: 1}$ as major or dominant components (Ueki \& Suto, 1979; Kohring et al., 1994; Vainshtein et al., 1992). Desulfovibrio sulfodismutans and Desulfovibrio carbinolicus have branched-chain fatty acids (anteiso- $\mathrm{C}_{15: 0}$, iso- $\mathrm{C}_{16: 0}$ or anteiso- $\mathrm{C}_{17: 0}$ ) as major components; by contrast, strain $\mathrm{BSY}^{\mathrm{T}}$ had saturated and unsaturated straight-chain fatty acids as major components but only trace amounts of branched-chain fatty acids. The DNA G $+C$ content of strain $\mathrm{BSY}^{\mathrm{T}}$ was almost the same as those of the type strains of Desulfovibrio sulfodismutans and Desulfovibrio carbinolicus (Table 2).

Thus, in addition to differences in 16S rRNA and DSR $\beta$ subunit gene sequences, the characteristics of strain BSY ${ }^{\mathrm{T}}$ 
Table 2. Differential characteristics between strain $B S Y^{\top}$ and the type strains of related Desulfovibrio species

Strains: 1, BSY ${ }^{\mathrm{T}}$ (D. butyratiphilus sp. nov.); 2, Desulfovibrio putealis $\mathrm{B} 7-43^{\mathrm{T}}$ (data from Basso et al., 2005); 3, Desulfovibrio sulfodismutans ThAc01 ${ }^{\mathrm{T}}$ (Bak \& Pfennig, 1987); 4, Desulfovibrio carbinolicus EDK82 ${ }^{\mathrm{T}}$ (Nanninga \& Gottschal, 1987). +, Used; -, not used.

\begin{tabular}{|c|c|c|c|c|}
\hline Characteristic & 1 & 2 & 3 & 4 \\
\hline Source & $\begin{array}{l}\text { Anaerobic municipal sewage } \\
\text { sludge }\end{array}$ & Deep subsurface water & Anoxic freshwater mud & $\begin{array}{c}\text { Anaerobic purification } \\
\text { plant }\end{array}$ \\
\hline Cell shape & Curved rods & Vibrio & Curved rods & Rods \\
\hline Motility & Motile & Motile & Motile & Non-motile \\
\hline \multicolumn{5}{|c|}{ Utilization of electron donors } \\
\hline Formate & - & - & - & + \\
\hline Butyrate & + & - & - & - \\
\hline Fumarate & - & + & - & + \\
\hline Malate & - & + & - & + \\
\hline Succinate & - & - & - & + \\
\hline Propanol & + & - & + & + \\
\hline \multicolumn{5}{|c|}{ Utilization of electron acceptors } \\
\hline Sulfite & - & + & + & + \\
\hline Fumarate & - & + & - & - \\
\hline \multicolumn{5}{|c|}{ Utilization of substrates in the absence of electron acceptors } \\
\hline Pyruvate & + & + & - & + \\
\hline Fumarate & - & + & - & + \\
\hline Malate & - & + & - & + \\
\hline $\begin{array}{l}\text { DNA G }+ \text { C content } \\
(\mathrm{mol} \%)\end{array}$ & 63.3 & 57.8 & 64.1 & 65.0 \\
\hline
\end{tabular}

were significantly different from those of recognized Desulfovibrio species especially with respect to utilization of electron donors and cellular fatty acid profiles. The sewage sludge strains are thus considered to represent a single novel species of the genus Desulfovibrio, for which the name Desulfovibrio butyratiphilus sp. nov. is proposed.

\section{Description of Desulfovibrio butyratiphilus sp. nov.}

Desulfovibrio butyratiphilus (bu.ty.ra.ti'phi.lus. N.L. n. butyras -atis butyrate; N.L. masc. adj. philus from Gr. adj. philos friendly to, loving; N.L. masc. adj. butyratiphilus butyrate-loving).

Cells are relatively large curved rods, $0.8-0.9 \mu \mathrm{m}$ wide and 2.4-5.6 $\mu \mathrm{m}$ long. Strictly anaerobic. Gram-negative. Motile by means of a single polar flagellum. Non-sporeforming. Colonies are greyish, thin and spread on agar slants. Contains desulfoviridin and cytochrome type $c$. Catalase- and oxidase-negative. Requires carbonate or bicarbonate in the growth medium. The $\mathrm{NaCl}$ concentration range for growth is $0-2.0 \%(\mathrm{w} / \mathrm{v})$ with an optimum at $0.5 \%(\mathrm{w} / \mathrm{v})$. The temperature range for growth is $25-40{ }^{\circ} \mathrm{C}$ with an optimum at $35^{\circ} \mathrm{C}$. The $\mathrm{pH}$ range for growth is 6.2-8.0 with an optimum at $\mathrm{pH}$ 7.1. Utilizes butyrate, 2-methylbutyrate, valerate, pyruvate, lactate, 1-propanol, butanol and $\mathrm{H}_{2}$ as electron donors for sulfate reduction. Almost all organic electron donors are incompletely oxidized to acetate; 2-methylbutyrate and valerate are oxidized to both acetate and propionate. Weak lithoautotrophic growth occurs with $\mathrm{H}_{2} / \mathrm{CO}_{2}$. Does not grow with formate, acetate, propionate, isobutyrate, isovalerate, caprylate, crotonate, fumarate, malate, succinate, methanol, 2-propanol, glycerol, glycine, L-alanine, L-serine, L-aspartate, L-glutamate, D-glucose, D-fructose or yeast extract under sulfate-reducing conditions. Sulfate and thiosulfate serve as electron acceptors, but not sulfite, nitrate or fumarate. Pyruvate supports weak growth in the absence of electron acceptors, but butyrate, lactate, fumarate and malate do not. The genomic DNA $\mathrm{G}+\mathrm{C}$ content of the type strain is $63.3 \mathrm{~mol} \%$. The major respiratory quinone is menaquinone MK-6 $\left(\mathrm{H}_{2}\right)$. Major cellular fatty acids are $\mathrm{C}_{14: 0}, \mathrm{C}_{16: 0}$, $\mathrm{C}_{16: 1} \omega 7$ and $\mathrm{C}_{18: 1} \omega 7$.

The type strain, BSY ${ }^{\mathrm{T}}$ (=JCM $15519^{\mathrm{T}}=\mathrm{DSM} 21556^{\mathrm{T}}$ ), was isolated from an anaerobic sewage sludge digester in Yokohama, Japan. Reference strain BST (=JCM 15520) was isolated from a digester in Tsuruoka, Japan. BSY-C, BST-B and BST-C are other strains of the species.

\section{Acknowledgements}

We are grateful to K. Takahashi for help with analysis of isoprenoid quinones. This work was partly supported by a Grant-in-Aid from the Institute for Fermentation, Osaka.

\section{References}

Akasaka, H., Izawa, T., Ueki, K. \& Ueki, A. (2003a). Phylogeny of numerically abundant culturable anaerobic bacteria associated with degradation of rice plant residue in Japanese paddy field soil. FEMS Microbiol Ecol 43, 149-161. 
Akasaka, H., Ueki, A., Hanada, S., Kamagata, Y. \& Ueki, K. (2003b). Propionicimonas paludicola gen. nov., sp. nov., a novel facultatively anaerobic, Gram-positive, propionate-producing bacterium isolated from plant residue in irrigated rice-field soil. Int J Syst Evol Microbiol 53, 1991-1998.

Altschul, S. F., Madden, T. L., Schäffer, A. A., Zhang, J., Zhang, Z., Miller, W. \& Lipman, D. J. (1997). Gapped BLAST and PSI-BLAST: a new generation of protein database search programs. Nucleic Acids Res 25, 3389-3402.

Bak, F. \& Pfennig, N. (1987). Chemolithotrophic growth of Desulfovibrio sulfodismutans sp. nov. by disproportionation of inorganic sulfur compounds. Arch Microbiol 147, 184-189.

Balk, M., Altinbas, M., Rijpstra, W. I. C., Damsté, J. S. S. \& Stams, A. J. M. (2008). Desulfatirhabdium butyrativorans gen. nov., sp. nov., a butyrate-oxidizing, sulfate-reducing bacterium isolated from an anaerobic bioreactor. Int J Syst Evol Microbiol 58, 110-115.

Basso, O., Caumette, P. \& Magot, M. (2005). Desulfovibrio putealis sp. nov., a novel sulfate-reducing bacterium isolated from a deep subsurface aquifer. Int J Syst Evol Microbiol 55, 101-104.

Beeder, J., Torsvik, T. \& Lien, T. (1995). Thermodesulforhabdus norvegicus gen. nov., sp. nov., a novel thermophilic sulfate-reducing bacterium from oil field water. Arch Microbiol 164, 331-336.

Belyakova, E. V., Rozanova, E. P., Borzenkov, I. A., Tourova, T. P., Pusheva, M. A., Lysenko, A. M. \& Kolganova, T. V. (2006). The new facultatively chemolithoautotrophic, moderately halophilic, sulfatereducing bacterium Desulfovermiculus halophilus gen. nov., sp. nov., isolated from an oil field. Microbiology (English translation of Mikrobiologiia) 75, 201-211.

Blenden, D. C. \& Goldberg, H. S. (1965). Silver impregnation stain for Leptospira and flagella. J Bacteriol 89, 899-900.

Collins, M. D. \& Widdel, F. (1986). Respiratory quinones of sulphatereducing and sulphur-reducing bacteria: a systematic investigation Syst Appl Microbiol 8, 8-18.

Cravo-Laureau, C., Matheron, R., Cayol, J.-L., Joulian, C. \& HirschlerRéa, A. (2004). Desulfatibacillum aliphaticivorans gen. nov., sp. nov., an $n$-alkane- and $n$-alkene-degrading, sulfate-reducing bacterium. Int J Syst Evol Microbiol 54, 77-83.

Daumas, S., Cord-Ruwisch, R. \& Garcia, J. L. (1988). Desulfotomaculum geothermicum sp. nov., a thermophilic, fatty aciddegrading, sulfate-reducing bacterium isolated with $\mathrm{H}_{2}$ from geothermal ground water. Antonie van Leeuwenhoek 54, 165-178.

Fardeau, M.-L., Ollivier, B., Patel, B. K. C., Dwivedi, P., Ragot, M. \& Garcia, J.-L. (1995). Isolation and characterization of a thermophilic sulfate-reducing bacterium, Desulfotomaculum thermosapovorans sp. nov. Int J Syst Bacteriol 45, 218-221.

Felsenstein, J. (2006). PHYLIP (phylogeny inference package), version 3.66. Distributed by the author. Department of Genome Sciences, University of Washington, Seattle, USA.

Hungate, R. E. (1966). The Rumen and its Microbes. New York: Academic Press.

Karkhoff-Schweizer, R. R., Huber, D. P. W. \& Voordouw, G. (1995). Conservation of the genes for dissimilatory sulfite reductase from Desulfovibrio vulgaris and Archaeoglobus fulgidus allows their detection by PCR. Appl Environ Microbiol 61, 290-296.

Kohring, L. L., Ringelberg, D. B., Devereux, R., Stahl, D. A., Mittelman, M. W. \& White, D. C. (1994). Comparison of phylogenetic relationships based on phospholipid fatty acid profiles and ribosomal RNA sequence similarities among dissimilatory sulfate-reducing bacteria. FEMS Microbiol Lett 119, 303-308.

Komagata, K. \& Suzuki, K. (1987). Lipid and cell-wall analysis in bacterial systematics. Methods Microbiol 19, 161-207.
Kuever, J., Rainey, F. A. \& Hippe, H. (1999). Description of Desulfotomaculum sp. Groll as Desulfotomaculum gibsoniae sp. nov. Int J Syst Bacteriol 49, 1801-1808.

Kuever, J., Rainey, F. A. \& Widdel, F. (2005). Class IV. Deltaproteobacteria class nov. In Bergey's Manual of Systematic Bacteriology, vol. 2, part C, 2nd edn, pp. 922-1144. Edited by D. J. Brenner, N. R. Krieg, J. T. Staley \& G. M. Garrity. New York: Springer.

Miller, L. T. (1982). Single derivatization method for routine analysis of bacterial whole-cell fatty acid methyl esters, including hydroxy acids. J Clin Microbiol 16, 584-586.

Miyagawa, E., Azuma, R. \& Suto, E. (1979). Cellular fatty acid composition in Gram-negative obligately anaerobic rods. J Gen Appl Microbiol 25, 41-51.

Moore, L. V. H., Bourne, D. M. \& Moore, W. E. C. (1994). Comparative distribution and taxonomic value of cellular fatty acids in thirty-three genera of anaerobic gram-negative bacilli. Int J Syst Bacteriol 44, 338347.

Nakamoto, M., Ueki, A. \& Ueki, K. (1996). Physiological properties of a sulfate-reducing bacterium isolated from municipal sewage sludge and its possible role as a syntrophic acidogen in the ecosystem. J Gen Appl Microbiol 42, 109-120.

Nanninga, H. J. \& Gottschal, J. C. (1987). Properties of Desulfovibrio carbinolicus sp. nov. and other sulfate-reducing bacteria isolated from an anaerobic-purification plant. Appl Environ Microbiol 53, 802809.

Postgate, J. R. (1959). A diagnostic reaction of Desulphovibrio desulphuricans. Nature 183, 481-482.

Rabus, R., Hansen, T. \& Widdel, F. (2000). Dissimilatory sulfate- and sulfur-reducing prokaryotes. In The Prokaryotes: an Evolving Electronic Resource for the Microbiological Community, 3rd edn. Edited by M. Dworkin, S. Falkow, E. Rosenberg, K.-H. Schleifer \& E. Stackebrandt. New York: Springer.

Saitou, N. \& Nei, M. (1987). The neighbor-joining method: a new method for reconstructing phylogenetic trees. Mol Biol Evol 4, 406425.

Schink, B. (1997). Energetics of syntrophic cooperation in methanogenic degradation. Microbiol Mol Biol Rev 61, 262-280.

Sekiguchi, Y., Kamagata, Y., Nakamura, K., Ohashi, A. \& Harada, H. (2000). Syntrophothermus lipocalidus gen. nov., sp. nov., a novel thermophilic, syntrophic, fatty-acid-oxidizing anaerobe which utilizes isobutyrate. Int J Syst Evol Microbiol 50, 771-779.

Sievert, S. M. \& Kuever, J. (2000). Desulfacinum hydrothermale sp. nov., a thermophilic, sulfate-reducing bacterium from geothermally heated sediments near Milos Island (Greece). Int J Syst Evol Microbiol 50, 1239-1246.

Stams, A. J. M. (1994). Metabolic interactions between anaerobic bacteria in methanogenic environments. Antonie van Leeuwenhoek 66, 271-294.

Suzuki, D., Ueki, A., Amaishi, A. \& Ueki, K. (2007a). Desulfopila aestuarii gen. nov., sp. nov., a novel, Gram-negative, rod-like, sulfatereducing bacterium isolated from an estuarine sediment in Japan. Int J Syst Evol Microbiol 57, 520-526.

Suzuki, D., Ueki, A., Amaishi, A. \& Ueki, K. (2007b). Desulfobulbus japonicus sp. nov., a novel, Gram-negative, propionate-oxidizing, sulfate-reducing bacterium isolated from an estuarine sediment in Japan. Int J Syst Evol Microbiol 57, 849-855.

Suzuki, D., Ueki, A., Amaishi, A. \& Ueki, K. (2007c). Diversity of substrate utilization and growth characteristics of sulfate-reducing bacteria isolated from estuarine sediment in Japan. J Gen Appl Microbiol 53, 119-132. 
Suzuki, D., Ueki, A., Amaishi, A. \& Ueki, K. (2008). Desulfoluna butyratoxydans gen. nov., sp. nov., a novel, Gram-negative, butyrateoxidizing, sulfate-reducing bacterium isolated from an estuarine sediment in Japan. Int J Syst Evol Microbiol 58, 826-832.

Tanaka, K., Stackebrandt, E., Tohyama, S. \& Eguchi, T. (2000). Desulfovirga adipica gen. nov., sp. nov., an adipate-degrading, Gramnegative, sulfate-reducing bacterium. Int J Syst Evol Microbiol 50, 639644.

Tasaki, M., Kamagata, Y., Nakamura, K. \& Mikami, E. (1991). Isolation and characterization of a thermophilic benzoate-degrading, sulfate-reducing bacterium, Desulfotomaculum thermobenzoicum sp. nov. Arch Microbiol 155, 348-352.

Thompson, J. D., Higgins, D. G. \& Gibson, T. J. (1994). CLUSTAL W: improving the sensitivity of progressive multiple sequence alignment through sequence weighting, position-specific gap penalties and weight matrix choice. Nucleic Acids Res 22, 4673-4680.

Ueki, A. \& Suto, T. (1979). Cellular fatty acid composition of sulfatereducing bacteria. J Gen Appl Microbiol 25, 185-196.

Ueki, A., Minato, H., Azuma, R. \& Suto, T. (1980). Enumeration and isolation of anaerobic bacteria in sewage digester fluids: enumeration of sulfate-reducers by the anaerobic roll tube method. J Gen Appl Microbiol 26, 25-35.

Ueki, A., Matsuda, K. \& Ohtsuki, C. (1986). Sulfate reduction in the anaerobic digestion of animal waste. J Gen Appl Microbiol 32, 111-123.

Vainshtein, M. B., Hippe, H. \& Kroppenstedt, R. M. (1992). Cellular fatty acid composition of Desulfovibrio species and its use in classification of sulfate-reducing bacteria. Syst Appl Microbiol 15, 554-566.

Vandieken, V., Knoblauch, C. \& Jørgensen, B. B. (2006). Desulfotomaculum arcticum sp. nov., a novel spore-forming, moderately thermophilic, sulfate-reducing bacterium isolated from a permanently cold fjord sediment of Svalbard. Int J Syst Evol Microbiol 56, 687-690.

Wagner, M., Roger, A. J., Flax, J. L., Brusseau, G. A. \& Stahl, D. A. (1998). Phylogeny of dissimilatory sulfite reductases supports an early origin of sulfate respiration. J Bacteriol 180, 2975-2982.

Watanabe, K., Watanabe, K., Kodama, Y., Syutsubo, K. \& Harayama, S. (2000). Molecular characterization of bacterial populations in petroleum-contaminated groundwater discharged from underground crude-oil-storage cavities. Appl Environ Microbiol 66, 4803-4809.

Widdel, F. \& Bak, F. (1992). Gram-negative mesophilic sulfatereducing bacteria. In The Prokaryotes, pp. 3352-3378. Edited by A. Balows, H. G. Trüper, M. Dworkin, W. Harder \& K.-H. Schleifer. New York: Springer.

Widdel, F., Kohring, G. W. \& Mayer, F. (1983). Studies of dissimilatory sulfate-reducing bacteria that decompose fatty acids. III. Characterization of the filamentous gliding Desulfonema limicola gen. nov. and sp. nov. and Desulfonema magnum sp. nov. Arch Microbiol 134, 286-294.

Zhang, C., Liu, X. \& Dong, X. (2004). Syntrophomonas curvata sp. nov., an anaerobe that degrades fatty acids in co-culture with methanogens. Int J Syst Evol Microbiol 54, 969-973. 